Portland State University

PDXScholar

1973

\title{
Transactional Analysis Jargon in Time Limited Groups
}

Diane Jones

Portland State University

Earl Eyre

Portland State University

Joan Logan

Portland State University

Follow this and additional works at: https://pdxscholar.library.pdx.edu/open_access_etds

Part of the Social Work Commons

Let us know how access to this document benefits you.

\section{Recommended Citation}

Jones, Diane; Eyre, Earl; and Logan, Joan, "Transactional Analysis Jargon in Time Limited Groups" (1973). Dissertations and Theses. Paper 1732.

https://doi.org/10.15760/etd.1731

This Thesis is brought to you for free and open access. It has been accepted for inclusion in Dissertations and Theses by an authorized administrator of PDXScholar. Please contact us if we can make this document more accessible: pdxscholar@pdx.edu. 


\title{
TRANSACTIONAL ANALYSIS JARGON IN
}

TIME LIMITED GROUPS

\author{
by \\ DIANE JONES \\ JOAN LOGAN \\ EARL EYRE
}

A practicum submitted in partial fulfillment of the requirements for the degree of

MASTER OF SOCIAL WORK

Portland State University 1973 


\section{ACKNOWLEDGMENTS}

We wish to acknowledge a number of individuals who have been instrumental in the construction of this practicum. We are deeply grateful to Mr. Lynn Thompson, faculty member at Portland State University School of social work. He not only reviewed the study at its completion, but from its inception has devoted countless hours in meetings and consultation. Mr. Thompson's dedication to this study, as our Practicum Committes Chairman, went far beyond the "call of duty." His skill and diligence provided direction, guidance, and support. In a real sense, he made this study possible. Appreciation goes to the other Practicum Committee members as well. Dr. Quentin D. Clarkson, of Portland State University, provided us with clear and concise details concerning statistical methods and analysis. Mr. Don Borjesson, of Lutheran Family Service, encouraged us in developing a study that would not only fulfill our Master's degree requirements, but provide useful information for Lutheran Family Service. 
Lutheran Family Service--the arena of this study-was very cooperative in allowing us access to the agency. The entire staff was helpful in preparing many facets of this study. Special thanks goes to the counseiors leading the Contract Groups. They cooperated in every way possible to provide accurate data, to assure efficient administration of the questionnaires, and to share valuable time from their contract group sessions for this study. We also wish to acknowledge the contribution of Mrs. Pat Evans, our typist, who spent many hours in preparing the final manuscript. Finally, we thank our families. This study has demanded a great deal of time away from our homes. Our families have patiently granted us this time, as well as encouragement in completing the research. 
TABLE OF CONTENTS

PAGE

ACKNOLLEDGMENTS . . . . . . . . . . • •

LIST OF TABLES . . . . . . . . . . .

CHAPTER

I INTRODUCTION. . . . . . . . . . I I

II REVIEW OF THE LITERATURE. . . . . . 3

Transactional Analysis Literature . 6

Components of Learning

Rosults of Learning

The Contract Group as a Life

Situation ...........

The Contract

Client/Counselor Relationship

Personal Change

il Rationale for the study . . . . .

TA in Groups.......... 14

TA at Lutheran Family Service. . . 14

Specificity of Jargon ...... 15

Time Limited Groups . . . . . . 16

Benefit to the Agency...... 16 
IV METHODS AND TECHNIQUES . . . . . . . 18

Establishing TA Jargon at Lutheren

Family Service... . . . . . 18

Construction of the Questionnaire. . 22

Time One Questionnaire

Time Two Questionnaire

The Pre-Test... . . . . .

Administration of Final Questionnaire. . . . . . . . . . . . .

Instructions

Methods of Administration

Problems of Administration

$\checkmark$ DESCRIPTION OF THE POPULATION. • • • •

VI ANALYSIS OF THE DATA ........... 38

The Jargon Questionnaires. . . . 38

General Over-All Learning

Primary and Secondary Words

Retention and Understanding

The Contract Group Experience. - .

Relationship between Contract Group

Experience and Learning of Jargon. .

VII SUMMARY OF FINDINGS. . . . . . . . 50

Conclusions. . . . . . . . 50

Boundaries of TA Jargon

Population

Learning of Jargon

Implications . . . . . . . .

Jargon

Contract Group Experience

Socialization 
vi1

PAGE

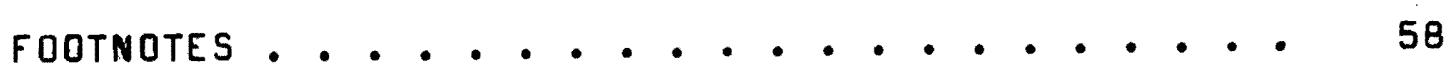

RESOURCES CONSULTED .................. 61

APPENDIX A: WORD SURVEY. ........... 64

APPENDIX B: RESULTS OF WORD SURVEY . . . . . . 69

APPENDIX C: ESTABLISHED JARGON AT LUTHERAN

FAMILY SERVICE. . . . . . . . . 72

APPENDIX D: THE QUESTIONNAIRE: TIME 1 AND TIME $2 \cdot 74$ 


\section{LIST OF TABLES}

TABLE

PAGE

I Example of Rating Scale Survey ...... 20

I Population Characteristics... . . . . 35

II Counseling Experience. . . . . . . . 36

IV Mean Improvement in Learning . . . . . 39

$\checkmark$ Mean Improvement in Primary and Secondary Words.......... 40

VI Mean Improvement in Retention and Understanding. . . . . . . . . . 41

VII Expectation and Success in Fulfilling

Contract. . . . . . . . . . 42

VIII Client/Counselor Relationship and Role of

Counselor . . . . . . . . .

IX Achievement of Contract and Personal

Changes... . . . . . . . . 43

$X$ Achievement of Contract and Perceived Help of Counselor. . . . . . . . .

XI Achievement of Contract and Client/

Counselor Relationship. . . . . . 44

XII Exposure to TA . . . . . . . . . . 
TABLE

PAGE

XII Exposure to TA and Time 1 knowledge of TA. 46

XIV TA Class and TIme 1 knowledge. . . . . 46

XV Previous Exposure to TA and Fulfillment: of Contract. . . . . . . . . . 47

XVI Previous Exposure to TA and Achievement of Contract . . . . . . . . .

XVII Improvement of Jargon Scores and Expected

Success in Mesting Contract. . . . 48

XVIII Improvement in Jargon and Achievement of

Contract. . . . . . . . . . 48

XIX Time 2 knowledge and Achievement of Contract................ 


\section{INTRODUCTION}

In 1964, Eric Berne published the book, Games People Play. I This book popularized a unique approach to psychotherapy called Transactional Analysis (TA). Other books such as I'm O.K. -You're $0 . K_{0}{ }^{2}$ by Thomas Harris and Born to Win ${ }^{3}$ by Muriel James and Dorothy Jongeward, have further stimulated popular interest in TA.

According to James and Jongeward,

TA... is a thought-provoking perspective of human behavior that most people can understand and put to use. It encourages the use of words that are simple, direct and often colloquial instead of psychological, scientific words or jargon... Its principles can be applied on the job, in the home, in the classroom, in the nelghborhood - whenever people deal with people.4

This quotation brings out several important assumptions about TA. First, it is stated that TA has an identifiable language, composed of common, easily understood terms. Second, it is assumed that people who wish to use TA theory must first learn the language. Third, once the language is learned, it is thought that these people can put it to use in their lives. This paper examines these three 
assumptions.

Lutheran Family Service (LFS) was chosen as the setting for this study primarily because of its uniqueness as the only social agency in the accessible geographic area which has TA as one of its primary theoretical orientations. LFS is an agency sponsored by the three Lutheran organizations in Oregon, offering services such as counseling, family life enrichment, training activities, group counseling and other community services.

One of the services offered at LFS is the contract group, a time-limited intensive group experieice. A contract group offers its eight to ten members 25 hours of group therapy which occurs within one month's time. Either three weekly four-hour sessions, or four week.iy three-hour sessions are held, plus a 13 hour nmarathon" group experience on a weekend. The contract groups at LFS provided us a "captive audience" to study the learninc of TA jargon. 


\section{CHAPTER II}

\section{REVIEW OF LITERATURE}

The purpose of this chapter is to provide a theoretical framework for this study. There will be three major sections in the literature review related to the three assumptions mentioned in the previous chapter. First, the premise that TA has a simple, identifiable jargon will be examined. Second, several theories of learning will be applied specifically to the learning of TA jargon. Third, a means of applying the learning process to a life situation* will be explored.

\section{TA LITERATURE}

The unique language of TA was designed to give both the client and therapist a rational process for analysing and understanding behavior. 6 The specific goal of using this method is to teach people open and genuine communication between the "affective and intellectual components of the personality. n7 Berne states that, almost without *This concept is further explained on page 11. 
exception, TA can be used to effectively deal with almost every type of mental or emotional disorder. 8 Although one may find TA's roots in psychoanalytic theory, TA grow out of a rejection of the elitism and complicated jargon of psychoanalysis, with terms such as id, ego, superego, cathexis, and libido. Such terms were understandable primarily to the therapist in assisting him to understand the patient's behavior. In contrast, the linguistic components of TA "are easier to teach effectively than most other clinical approaches, ${ }^{9}$ because the method proceeds in stages which can be clearly. defined, allowing both the therapist and the client to clearly see at the same time the therapeutic position the client is in. Jargon is a very special feature of TA. Webster defines jargon as "the technical terminology or characteristic idiom of a special activity or group.n10 TA's language was designed to be both understood by and attractive to the majority of those people seoking counseling. 11,12 The TA method is taught and practiced through a number of words which Berne calls "colloquial,"13 that are informal, easy-to-understand adaptations from other complex, psychiatric concepts. Berne was deliberate in his development of a language or jargon that client and therapist understand equa 11y.

It is the intention of the therapist to communicate with the patient on all the aspects of his thinking in regard to treatment. Thus, TA has as one of its basic tenets, that for efficient 
behavior modification it is desirable that the patient and therapist use a language which is capable of being understood by both.14

Thus, Berne has proposed TA jargon as an answer to the plea of one speaker at the 1965 American Psychiatric Association's annual meeting that "...psychiatry must develop a 'public language,' decontaminated of technical jargon and suited to the discussion of universal problems in our society. $n 15$

Berne states that even those individuals with very limited intelligence as measured on psychometric scales, can understand $T A^{\prime}$ 's concepts through its simple jargon. In addition, he states that TA has been effective in groups whose members had a wide range of disorders, without regard to factors such as age, intelligence, severity of problems, experience with psychotherapy or social class. ${ }^{16}$ steiner also states that the ideal group has as its members people who are diverse in as many aspects as possible. 17 It is preferable, then, for the group to have eight different problemg, rather than eight alcoholics or eight schizophrenics. 18

Literature during the past two decades regarding TA consistently supports the viow that TA jargon is in fact easily identifiable, readily understood by both therapist and clisnt, is adaptable to persons with a diversity of disorders, and may be used in various therapeutic modes, for example, one-to-one, small group, etc. 
LEARNING THEORY APPLIED TO TA JARGON

Since knowledge of TA jargon is acquired through a learning process, it was assumed that this process would be consistent with general learning principles. Many general principles in the literature on learning theory are applicable to specific methods and experiences utilized in learning TA jargon and translating it behaviorally into action. This section will examine learning theory and its relationship to TA jargon.

\section{Components of Learning}

Learning is influenced by a number of variables which, for the sake of clarity, will be discussed separately. In practice, however, many of them overlap and occur simultaneously.

Mode of Impression. It is generally felt that a multi-modal approach, including visual, auditory, kinesthetic, or vocomoter, is more effective in promoting learning than the use of only one mode. ${ }^{19}$ TA is taught through readings, lectures, diagrams, conversation in jargon and experiential groups.

Meaningfulness. Meredith refers to meaningfulness as the process of intelligent interpretation, that is, pinding a relationship between learned material and similar life experience. 20 It doesn't matter, he says, if words have several meanings, as long as the meaning is clear within 
the context. Establishing the context is an integral part of the learning process. One of the distinctions about TA is its utilization of simple, commonly used words to construct a epecific theoretical framework, and in the context of this framework, to introduce a jargon where these same words now are used in new ways to connote new meanings.

Use of Vocabulary. Most literate adults have amased a vocabulary of tens of thousands of words. Most of these words have historles long antedating recent generations, and have come, through many speech transactions and contexts of experience, to carry certain meanings. As each person's Ilfe experience varies, so do the meanings he gives to words as he learns them against the framework of associations. He is also influenced by the word usage of other people with whom he shares portions of his life. Therefore, to place these words in a new context and to give them new meanings, requires practice in now verbal transactions, new frames of reference, and application of "old" words to new life experiences. 21 The key factor in learning TA jargon is the consistency with which colloquial words are given different meanings within a new frame of reference. Affective Toning. Experiences which are merkedly pleasant or unpleasant are more easily recalled than those experiences with neutral or indifferent emotional contexts. In TA groups, clients are encouraged to apply the concepts 
learned to current life situations. Translating the pleasant and unpleasant experiences into the new terminology Increases, it is thought, affective involvement which reinforces learning.

Motivation. A learning task must offer some chance of success at the outset or there is little involvement by the learner. If the learner is satisfied with the taak, his learning is greater. A sense of impending failure and a low solf esteom tend to impede learning and subsequent performance based on that learning. 22 The positive approach indicated in the titles of the two major textbooks clients at L'FS are asked to read (I'm O.K.--You're Q.K. and Born to Uin), represents a strong emphasis on building a sense of self worth and optimism in one's ability to make desired changes.

Anxiety. Complex tasks are adversely affected by anxiety. However, anxiety seems to facilitate simple learning tasks where responses are clear. Therefore, it makes sense that. in introducing an anxious individual to a new learning situation, the use of simple language, direct methods and clear concepts is highly desirable. The originator and users of TA see its colloquial jargon and easily explained theory as extremely facilitative in engaging clients in treatment, and assisting them in improving along desired lines, thus reducing their anxiety at the outset. 
Verbal Learning. Rote memorization and blind repetition are not sufficient for learning. In learning, the processes of understanding and retention come into play. Underwood and Schulz divide verbal learning into two stages: 1) "response-recall" phase, during which responses become readily available, and 2) "associative" phase, where a "hook-up" relationship develops between the response and the specific learning stimulus which precedes or accompanies it. 23 Therefore, retention without understanding is possible, as is understanding without remembering. Meredith stresses, however, that knowledge is stored, and "sooner or later" can be remembered if it was at one time understood. 24 He does not exclude rote memorization, however, but rather sees it as a vehicle. "For understanding, you must see through the words to the meanings, but for memory, you must pick up the words again to preserve a form of expression. ${ }^{25}$ Again, in the approach of TA contract groups, instructional and experiential aspects are interrelated. The jargon and theory of $T A$ is memorized, then it is utilized in dealing with the client's "contract" in a group setting, and hopefully is integrated into his daily 11fe. He draws again on the products of rote memory (jargon) to express to himself and others his life experiences. 


\section{Results of Learning}

Although the present study does not deal with observable behavioral changes which may occur as a result of participation in contract group, it is impossible to totally disrogard the behavioral implications of learning TA jargon. Leys looks at the behavioral role of learning from two viewpoints. On the one hand, he stresses that any significent change within a person, i.e., a learning experience, can be expected to manifest itself in some change in behavior. On the other hand, in observing a change in outward behavior, he presumes premexisting inward change.

Leys recommends caution in attributing the credit for observable changes in behavior solely to the learning process in which the person is currently engaged. With the flood of stimuli to which most intellectually oriented adults are exposed, it is difficult to discriminate which factors are primarily influencing the changes in behavior observed. 26

In summary the foregoing literature roviow identified several conditions or principles necessary to maximize learning. These principles are consistently used in the teaching and learning of TA jargon, providing an optimum setting for learning. Furthermore, if learning occurs, it can be expected to manifest itself behaviorally. 
THE CONTRACT GROUP AS A LIFE SITUATION

Once TA jargon is learned, the literature indicates that this knowledge can be put to use in one's life, and this application will be evidenced in behavioral change. The contract group is one such life situation which provides opportunities for behavioral change. Examples of behavioral change are: the making and fulfilling of a contract, establishment of a satisfactory client/counselor relationship, and the making of personal changes facilitated by the client-counselor relationship. This section of the literature review will deal with material applicable to these issues.

\section{The Contract}

Ripple discovered that a client was more likely to complete therapy if both client and counselor agreed on their definitions of the client's problem and situation. 27 The relevance of this finding is readily apparent. Unless the client and counselor could very quickly agree on the nature of the problem, the client was very likely to drop out early in the treatment process. 28 At the beginning of the contract group experience at LFS, the client is strongly encouraged to engage in a contract with his counselor to work toward achieving his goals. James and Jongeward say:

A contract must be clear, concise and direct. It involves (1) a decision to do something about a 
specific problem, (2) a statement of a clear goal to be worked toward in language simple enough...t to understand, and $(3)$ the possibility of the goals

\section{Client/Counselor Relationship}

Much research has been done on the effect of the helping relationship between clients and counselors. Much of this emphasis may go back to casework's roots in psychoanalytic theory and its stress on the transference relam tionship. Many caseworkers conjectured that if the roots of psychological disturbence originate in the early motherchild relationship, then a new, enduring, nurturing relationship is needed. "A relationship that gives this sense of freedom of verbal expression often provide a new and welcome experience to those who are in distress... 30 Ressarch indicates that a positive relationship between the counselor and client is, in fact, necessary to facilitate change. 31 At LFS the contract group setting provides a backdrop for the development of a one-to-one counselor/ client working relationship which is seen as a necessary part of the treatment process.

\section{Personal Change}

Gandy and Tapperman have recently completed an extensive evaluation of a Public Neighborhood Service Center, comparing different types of services offered by the agency. 32 They found that client satisfaction was 
highest when the client felt that his problems were primarily intrapersonel and when he felt the counselor had done all in his power to help him with his problems. Clients at LFS are encouraged to focus on making personal changes, and the counselor can be relied upon to participate actively in this process.

In summary, for purposes of this study, the contract group is defined as a life situation which provides opportunities for behavioral change. The literature supports the validity of exploring several areas where change may occur. 


\section{RATIONALE FOR THE STUDY}

It seomed preferable to conduct this study in as ideal a setting as possible. A group situation was sought in accordance with the literature which afpirms that TA in a group setting is "ideal.n 33,34

\section{TA IN GROUPS}

"TA is best done in therapy groups; or conversely, it may be said that the natural function of therapy groups is TA.n 35 Berne offers TA as a method of group therapy because "... it is a rational, indigenous approach derived from the group situation itself. $n^{36}$ According to James " and Jongeward, the group setting enables people to become more aware of themselves, to see their personality in a clear context such that they can see ways to change the parts that they desire. 37

\section{TA AT LUTHERAN FAMILY SERVICE}

Several years ago, LFS therapists inaugurated new approaches to group counseling which they felt were more 
effective than traditional methods. These techniques include TA, Gestalt therapy, encounter and sense awareness, and are used with the primary goal of enabling clients to increase their problem-solving skills.

$$
\text { Of TA, LFS says, }
$$

Transactional Analysis is a new way of talking about human behavior... The words which are used are specifically defined words, simple, colloquial and direct. With these words, anyone can converse with meaning about what goes on between pereons. TA is unique in its reduction of human behavior to a basic unit for observation, the transaction... $T A$ is a teaching and learning device... a tool which can help you decide what to do with a rather clear understanding of what it is you are doing. Can everyone learn it? Yes...essential concepts (are) Parent, Adult, Child, O.K., Not-O.K., Games, Stroking... 38

The authors of the present study each had previous knowledge and/or experience with $T A$, and one of the authors was in field placement at LFS at the time the study began. For practical purposes, this would facilitate the research process in making necessary personal contracts, arrenging for administration of questionnaires, understanding and analyzing data and gaining clarity about the focus of the study within the overall context of the agency and its broader functions.

\section{SPECIFICITY OF JARGON}

Aside from the fact that TA provides the primary theoretical basis for counseling at LFS, it was chosen for study for several other reasons. TA has a clearly identi- 
fiable and definable jargon, which lends itself easily to objective examination. It was felt that learning, retention and understanding of the basic TA vocabulary could be accurately measured because of the specific nature of the jargon, and widespread agreement among LFS counselors as to what the essential TA words are.

\section{TIME-LIMITED GROUPS}

It was decided to conduct the study through the vehicle of contract groups to assure a stable population and to facilitate a before-after testing situation, within a predictable time period. Interest in researching the learning and utilization of TA in time-limited groups arose from growing awareness of the methodical and thorough process used by the agency to teach clients TA theory and jargon. This process begins at the outset of therapy, and use of the unique TA terminology continues throughout the client's contacts with the agency.

\section{BENEFIT TO THE AGENCY}

The fact that a great deal of time and effort is expended by agency personnel in teaching TA theory and jargon to clients seomed to validate taking a look at how effectively the jargon is learned and understood. The focus of this descriptive study was limited to the learning and utilization of TA jargon. 
The agency concurred that this study could potentially provide valuable data not avallable previously, regarding the role of TA jargon in the overall treatment process. Hopefully, this data would contribute to other evaluative activities LFS is conducting. The description of the population, such as biographic characteristics of contract group population, and subjective data rogarding the contract group experience, were included to give direction for possible future research.

It is understood that learning of TA jargon per $s 8$, comprises only portion of the counseling experience of LFS clients. TA was chosen for study rather than Gestalt, sense awareness or encounter methods because of its unique claims of conciseness of language and clarity of theoretical Pramework. 
CHAPTER IV

METHODS AND TECHNIQUES

\section{ESTABLISHING TA JARGON AT LFS}

Three resources were useful in attempting to identify TA jargon. First, the literature was surveyed in order to find what TA jargon the "experts" in TA used in their writings or termed "important." For example, Berne states that there are six main words that comprise the most importent words for the perspective client to know: Parent, Adult, Child, Pastime, Script and Game. ${ }^{39}$ A list of the words found in the literature was made. Second, pamphlets and other literature distributed by LFS were obtained. New additions to the TA jargon list were made. Third, audiotape recordings of group sessions at LFS were obtained. By listening to the recordings and noting TA jargon the counselors and clients used, the authors were able to further expand the list of TA jargon. When these resources were exhausted, pinal list of eighty-three TA terms resulted.

In order to identify the TA terms the counselors at 
LFS felt were important for their clients to know, the LFS counselors were asked to rate each of the eighty-three terms according to the word's "importance" for the client to know.

In assombling the list of the TA words found in the literature and tape recordings that could qualify as "TA jargon at LFS," the authors found that some TA words were difficult to distinguish from those associated with other theories, e.9., Gestalt. The confusion that was encountered might have been attributed to the fact that in addition to TA, Gestalt therapy is extensively used at LFS. Dus to the fact that this study was concerned with TA jargon indigenous to LFS, the focus rested on what the counselors at LFS considered to be TA jargon. Indeed, an interesting question was whether or not TA jargon could be discerned from the jargon of other therapies by the counselors. Thus, to the list of eighty-three words were added an additional ten words from other disciplines, particularly Gestalt and Behavior Modification therapies. This was done to mix "pure" TA terms with words from other theories to see if LFS counselors would make differentiations, and second, to rate the words as to their importance.

The rating scale was constructed by randomizing the ninety-three terms. The counselors were instructed to rate each word according to two categories: whether or not it was, in fact, a TA word, and if the word was TA 
jargon, the counselor was asked to rate each word by placing an " $x$ " in the appropriate box, and to judge how importent the word was for the counselor's clients to know to effectively engage in treatment at LFS. If the word was not $T A$, the counselor was asked to note this by placing an " $x$ " in the category, "Not TA."

TABLE I

EXAMPLE OF RATING SCALE SURVEY

Most Somewhat Not Not Important Important Important TA

\begin{tabular}{l|l|l|l|l}
\hline Top Dog & & & & \\
\hline Message & & & & \\
\hline "little profeseor" & & & & \\
\hline Archaic elements & & & & \\
\hline
\end{tabular}

(See Appendix A for complete survey.)

The plan for the survey was to administer it to the ten full-time counselors at LFS. Mine out of ten counsolor were avallable to complete the rating survey. Elght completed and roturned the rating ourvey and one falled to return 1 t.

The results of the survey were complled by assigning a number to each category of evaluation. More specifically, the number three was assigned to the category "Very Important for the Client to know," two was assigned to "Somewhat Important for the client to know," and one to "Not Important for the Cllent to know." Zero was reserved 
Por the category, "Not TA." A tally was kept for each word and the ratings the eight counselors assigned it. Thus, a score of 24 for a word showed perfect agreement between all eight counselors $(8 \times 3=24)$, that the word was very important for the client to know in order to effectively engage in treatment at LFS.

The scores ranged from 24 to zero (see Appendix B for word scores). The top 19 words were chosen for the final questionnaire. This was due to the fact that they had high scores of 24 to 22 , representing agreement equal to or above 91.7\%. For the purposes of this research, these 19 words vere designated as comprising the "established jargon at LFS" (see Appendix C), or those words most likely to be taught by LFS counselors.

The only word that received unanimous score of zero (which was agreement by eight therapists that the word was "Not TA") was the term, "underdog," which is found in great Prequency in Gestelt literature, and nowhere in the TA literature surveyed. However, the terms "fantasy," "awareness," "here and now," "dream work," "gestalt" and "impasse," found in Gestalt literature but not found in TA literature, were identified as TA words. They received scores of 19, $18,10,8$ and 6 , respectively. One may account for these results by noting that, in practice at LFS, Gestalt and TA terms are intermingled. 


\section{CONSTRUCTION OF THE QUESTIONMAIRE}

Having compiled a list of the most important TA terms for the clients to know at LFS, they could then be used as the jargon to be tested with contract group clients. A questionnaire was constructed to be administered at the beginning of a contract group. It contained the following areas of information to be gathered: 1) "Biographic Information," concerning the client's background, and 2) a section regarding the client's knowledge of TA jargon.

A second questionnaire, to be administered at the conclusion of the contract group, also consisted of two parts: 1) a "General Information" section regarding the client's perception of the contract group experience, and 2) a TA jargon section identical to that in the first questionnaire (see Appendix 0 ). Each questionnaire will be discussed separately.

\section{Time 1 Questionnaire}

Blographic Information. The purpose of gathering biographic information about the client population was in response to a request made by LFS. The agency expressed interest in the information from this section in order to assemble additional data on the characteristics of its clients.

In addition to the agency's use, the comparisons of 
this section with the other two sections was thought to yield interesting information. For example, does level of education, age, etc., have"anything to do with how well a client learns TA jargon?

The items in this section were chosen to supply the most useful information about the clients assigned to contract group treatment. This section, along with others, was kept brief due to the attempt made to construct a manageable questionnaire that required a minimum amount of time for the subjects to complete.

Twe kinds of information were important: first, information as to the client's sex, age, education, and race; and second, information that pinpointed the client's familiarity with TA and with LFS. There were three ways a client could have prior knowledge of TA: 1) if one had been in therapy at a previous time in which TA was used as a theoretical framework; 2 ) if one had read books or pamphlets, or attended TA lectures; or 3 ) if one had attended an evening Introduction to TA class at LFS. The purpose of this section was to find if the new clients were familiar with TA before they started the contract group, and if so, how they obtained that knowledge. Also, it would be useful to know if the clients had made use of the TA evening class.

Knowledge of TA Jargon. This section was constructed by first deciding that two areas of learning would be 
explored: "rote memory" and "understanding." To manage the size of the questionnaire, it was decided that sixteen questions would comprise this section, and that eight words would be raridomly chosen from the original nineteen to test for "rote memory," and eight additional words would be selected randomly from the remaining eleven words to test for "understanding."

The eight questions testing for "rote memory" were constructed by giving a definition in the body of the question and asking the client to choose between four possible words, which word matched the definition. The elght questions on "understanding" also involved multiple choice answers. However, this time the client was given a situation that illustrated the use of the particular word. Not only did the client have to know what the word meant, but he had to "understand" the word so that he could apply it in the situational question.

The correct answers to these questions, along with three "wrong" answers, were placed in random order. Effort was made to choose "wrong" answers that would seem appropriate in the commonly used context (other than TA) of the word, especially if the client had no knowledge of the meaning of the TA word. This is based on TA's claim that commonly used words are taken from their original context and relearned within a new framework. 


\section{Time 2 Questionnaire}

One section of the Time 2 questionnaire tested the client's knowledge of TA jargon. The other section of the Time 2 questionnaire is discussed below.

General Information. This section, focusing on client's perceptions of the contract group experience, was added to the questionnaire after some deliberation. Other methods, such as measurement of client "movement" (change), were considered and discarded as not appropriate for this study and/or difficult to operationalize. The perceptions of the client regarding specific facets of his contract group experience could have implications as to the value he placed on his contract with LFS. In addition, it was surmised that the client's perceptions of the contract group experience had some relationship to learning of jargon.

The following issues were of interest in an attempt to ascertain client's perception of the contract group experience at LFS: 1) the client's additional knowledge of TA since the start of the group obtained outside of the contract group environment; 2) the client's contract with the counselor; 3 ) the counselor/client relationship; and 4) the client's reports of personal change. If the client had acquired additional knowledge of TA since the beginning of the contract group, the results of this additional learning may have influenced the client's 
performance on the questionnaire. The source of this additional knowledge was also of interest. Thus, the format found in the blographic information section for pinpointing this knowledge was used. The client was asked If he had increased his knowledge of TA since the beginning of the contract group either by the evening Introduction to TA class offered by LFS or by books, pamphlets, television programs or public lectures. If the client answered negatively to these questions, it was interpreted to mean that he had not increased his knowledge of TA outside of the group, and thus, any incresse in learning of TA jargon from Time 1 to Time 2 would be attributed to learning within the context of the contract group.

It was felt that information regarding the client's contract would be gathered for two reasons: 1) for collecting descriptive data on the client population; and 2) to see if there was a relationship between the making and fulfilling of a contract and the learning of TA jargon. If the client made a contract, three areas were important: 1) the client's definition of his contract; 2) the expected degree of success of fulfilling the contract at the start of the contract group; and 3) the evaluated degree of success in achieving the contract at the close of the contract group. Because of the importance placed on the contract as a precursor to behavioral change, it was thought that the client's evaluation of his contract -- 
his opinion of his expectations and his subjective feelings of his success in reaching his contract - had a velid. place in the questionnaire.

Three questions were designed to yield information regarding the counselor/client relationship. The first question was centered on the relationship between the client and his counselor. The second and third questions asked the client whether he achieved personal change, and if so, to what degree did the counselor aid the client in making personal change. The rationale for asking these questions was to gather information regarding the following issues: To what extent does the relationship between the client and his counselor affect a client making and percoiving success in fulfilling a contract? What relationship is there between a good counselor/client relationship and the client's personal change?

THE PRE-TEST

The questionnaire was pre-tested with the cooperation of two group counselors in a contract group composed of eight clients. Two of the authors went to the final session of the contract group with the permission of the counselors to explain and administer the questionnaire.

The group counselors had explained to the group the preceding weok that a brief survey would be conducted at that session jointly for LFS and for Portland State Univ- 
ersity School of Soclal Work. The group members had been reassured concerning confidentiality and anonymity, and were told that the counselors would not have access to the questionnaire.

As several members arrived late, administration of the questionnaire was delayed longer than planned, thereby taking more time from the session than had been expected. After the questionnaires were distributed, one of the authors read the printed questions regarding the instructions and allowed time for all to complete the questionnaire. Group members were asked to double-check their completed forms to see that all questions were answered according to directions, after which they were collected. In addition to demographic data and TA content, the preliminary questionnaire contained a final section regarding the client's perception of the clarity of the verbal and written instructions and the clerity of the questions, as well as space for additional comments. Although there were no written comments indicating negative reactions to the administration of the questionneire, the counselors reported extensive negative feedback shared verbally by group members after the authors had left. Clients expressed negative feelings about "outsiders" attending portions of the group sessions, about using counseling time to fill out the questionnaire, about possible risks in disclosure of identity and breach of confidentiality. The counselors 
felt that the questionnaire having been administered by "outsiders" was the chief anxiety-producing factor, and surmised that if this factor could be eliminated, probably other objections would be overcome. Along with minor changes in the body of the questionnaire such as wording and page design, it was decided to devise a way for the authors to avoid actually being present at the contract groups. Because of the excellent spirit of cooperation of the two counselors, and their willingness to assist in facilitating the process, this goal was achieved. The counselors offered to administer the questionnaire at the beginning and the end of subsequent contract groups, without having access to its content themselves, either before or after its completion. They also cooperated in declining to discuss the content with clients at any time. Both counselors and clients were aware that upon completion of the study, the results would be available to them. They were given written instructions to read to their contract groups, after which group members would complete the questionnaires, re-check and return them. Completed questionnaires were collected by the counselors, placed in a box and left at the agency to be picked up the following day. 


\section{ADMINISTRATION OF FINAL QUESTIONNAIRES}

\section{Instructions}

Instructions for the questionnaires were comprised of both verbal and written directions. In addition to informing the clients of the specific way in which to complete the questionnaires, the following issues were covered: a) individual performance was not important since results would be assessed within each contract group, which made individual performance of little concern. In order to keep anxiety to a minimum; the clients were informed that although much of the material would be unfamiliar, they were asked to answer the questions using their best judgment; b) anonymity would be preserved by the use of the last four digits of the client's telephone or social security number as coding numbers, which allowed the authors to match the individual's Time 1 and Time 2 questionnaires; c) results of the study would be available at LFS in the spring of 1973 to all those interested; and d) the research was part of a practicum at Portland State University School of Social Work for LFS.

The pros and cons of informing the group members that they were to be tested twice were weighed, and it was decided that clients would be informed only at the time of each testing that they were being asked to participate in this study. This was to limit the amount of anxiety on the 
part of the client regarding his performance on the Time 2 questionnaire, and to prevent him fromconsciously or unconsciously preparing for the final questionnaire in such a way that his Time 2 performance would be affected.

In deciding how the test was to be administered, it became obvious that it would be necessary to prevent the group counselors from having knowledge of the specific elements being studied or the purpose of the questionhaires. This was considered important in order to avoid any conscious or unconscious effort to focus on test-related items during the remainder of the contract group.

Method of Administration

The administration of the questionnaires involved a relatively simple operation: a box was delivered to LFS prior to the beginning and end of each contract group. This box contained the questionnaires and the cover sheet explaining the test procedure, a shest of verbal instructions to be read aloud by the group counselor that emphasized essential elements in the test procedure, and pencils and lap boards to assist the client in completing the test with ease. The group counselor was asked to remove and distribute the items in the box and read the verbal instructions to the group members. Upon completion of the procedure, the group counselor was asked to return all items to the box and place the box in a prearranged area for pick-up the following day. This procedure was repeated 
at the beginning and at the end of each of five contract groups. The completed questionnaires were labeled as to their group number and test time.

Problems of Administration

There was one difficulty in the administration of the questionnaire. One of the counselors terminated a contract group one week prior to the agreed termination date. Because the authors were not aware of the change in the date of termination, the box of test materials was not provided and the group members did not complete the Time 2 questionnaires. After some discussion, it was decided that the authors would attempt to make contact with each group member by mail and request that they complete the Time 2 questionnaire. In order to continue to preserve anonymity, a secretary at LFS was enlisted to match identification numbers from the Time 1 questionnaires with names and addresses. A cover letter from the agency was enclosed with the Time 2 questionnaire, explaining that the agency would appreciate their cooperation in completing the questionnaire. An addressed, stamped envelope was enclosed. Follow-up telephone contacts were also made by the agency to encourage return of the questionnaires. From the nine members contacted by mail, five completed questionnaires were received. Because of the reduction in sample size resulting from the incomplate test returns, it was 
33

decided to include a fifth contract group to maintain the desired population size. 


\section{CHAPTER $V$}

\section{DESCRIPTION OF POPULATION}

The population for the study consisted of 36 individuals who participated in time-limited "contract groups" at LFS.

Major findings (ser Tables. II and III) reflected that roughly $60 \%$ of the population studied was female, with $60 \%$ over 35 years of age. The population was $97 \%$ Caucasian. Educational data showed that $20 \%$ had had post-baccalaureate graduate education, an additional $60 \%$ had attended and/or graduated from college, and the remaining $20 \%$ had completed high school. The median average education completed was 14 years.

Over $50 \%$ of the population came to the agency with previous counseling experience, and $45 \%$ of these had had counseling utilizing $T A$ as a treatment method.

of the total population, $66 \%$ had become acquainted to some degree with TA through lectures, books, TV programs or pamphlets before entering the contract group. An introductory two and one-half hour evening class offered by the 
agency, which covers the basic fundamentals of TA was attended by $60 \%$ of the population prior to the contract group.

Some clients have individual or group interviews at LFS before entering contract groups. Of the population, $22 \%$ had three or more interviews of this nature, $42 \%$ had one or two sessions, and $36 \%$ had no initial interviews preceding the contract group.

\section{TABLE II}

POPULATION CHARACTERISTICS

\begin{tabular}{|c|c|c|}
\hline Biographic Issues & Number & $\%$ of Total Population \\
\hline $\begin{array}{l}\text { Sex: } \\
\text { Male } \\
\text { Female } \\
\text { Total: }\end{array}$ & $\begin{array}{l}14 \\
\frac{22}{36}\end{array}$ & $\begin{array}{l}38.9 \% \\
62.1 \\
100.0 \%\end{array}$ \\
\hline $\begin{array}{l}\text { Age: } \\
19 \text { or less } \\
20=25 \\
26=30 \\
31=35 \\
36=40 \\
41=45 \\
46=50 \\
\text { Total: }\end{array}$ & $\begin{array}{r}0 \\
3 \\
4 \\
7 \\
11 \\
5 \\
6 \\
36\end{array}$ & $\begin{array}{l}0.0 \% \\
8.3 \\
11.1 \\
19.4 \\
30.6 \\
15.9 \\
16.7 \\
100.0 \%\end{array}$ \\
\hline $\begin{array}{l}\text { Race: } \\
\text { Caucasian } \\
\text { Black } \\
\text { Total: }\end{array}$ & $\begin{array}{l}35 \\
\frac{1}{36}\end{array}$ & $\begin{array}{r}97.2 \% \\
2.8 \\
100.0 \%\end{array}$ \\
\hline $\begin{array}{l}\text { Education: } \\
\text { Completed High School } \\
\text { Attended or Completed } \\
\text { College } \\
\text { Post-Baccalaureate } \\
\text { Education } \\
\text { Total: }\end{array}$ & $\begin{array}{r}8 \\
21 \\
\frac{7}{36}\end{array}$ & $\begin{array}{l}22.2 \% \\
58.3 \\
\frac{17.5}{100.0 \%}\end{array}$ \\
\hline
\end{tabular}


TABLE III

COUNSELING EXPERIENCE

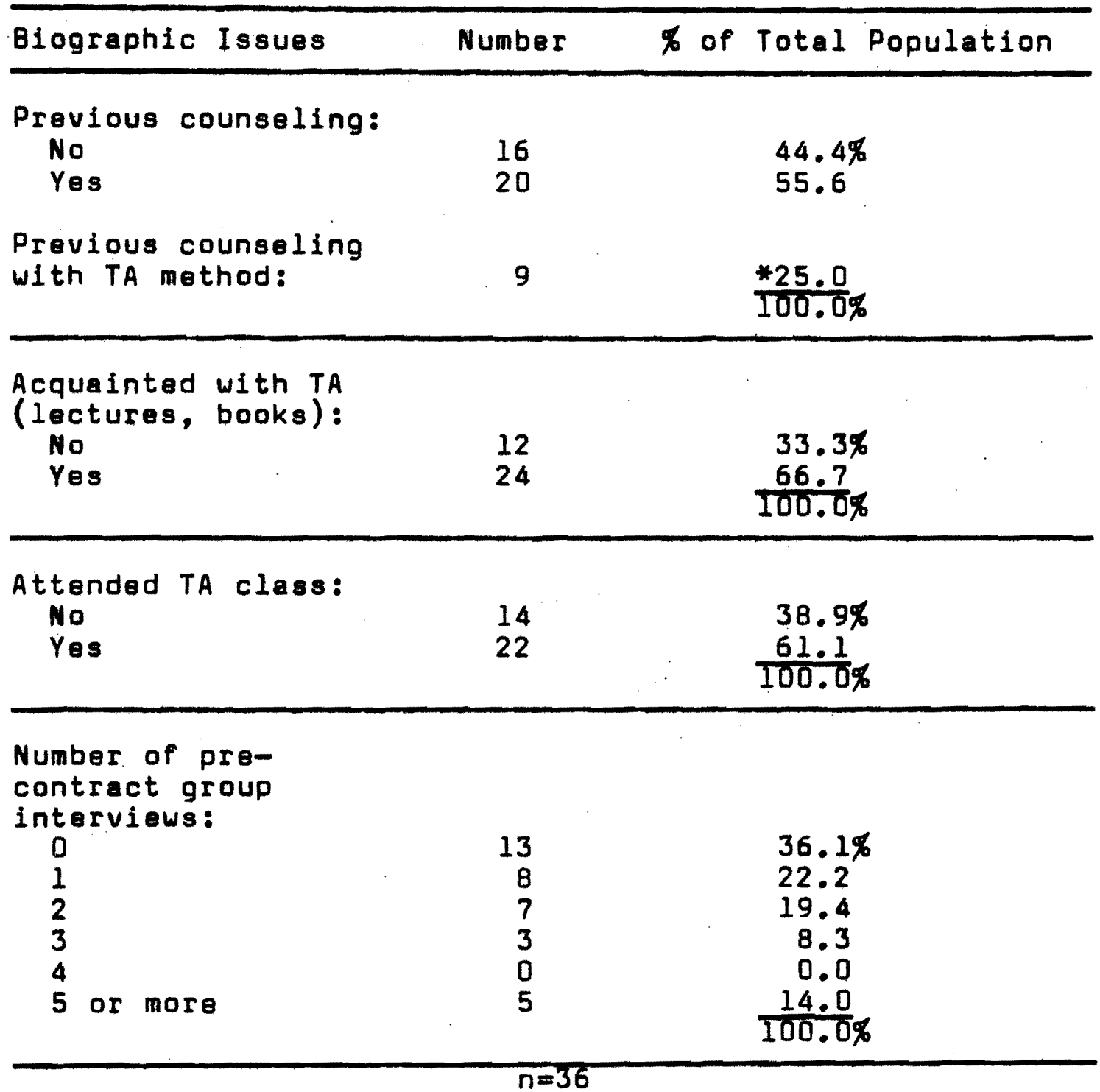

* of the 20 members who had had previous counseling, $45 \%$ had experienced TA as a treatment method. The $25 \%$ pigure is for the entire population.

From the information in the above tables, it is possible to construct a somewhat accurate composite picture of a "typical" contract group client. She is white, female, about 38 years of age, and has had $2 \frac{1}{2}$ years of post high 
schiol education. She has had previous counseling experience, which may or may not have utilized TA.' She comes to the contract group with a background in TA acquired through lectures or books, and the completion of a Thursday evening two and on-half hour introductory TA course, which further acquaints her with the fundamentals of TA.

She may have been referred at the time of application to the contract group, or she may have had one initial interview with an LFS counselor. 
CHAPTER VI

ANALYSIS OF THE DATA

The analysis of the data is divided into three sections: the jargon questionnaires, the contract group experience, and the relationships between learning TA jargon and the contract group experience.

THE JARGON QUESTIONNAIRES

It was decided to discard any questions that were missed by at least $75 \%$ of the population at both Time 1 and Time 2. These questions, it was felt, would reflect that either the group leaders did not teach that concept or the question was poorly worded. Based on this rationale, question number 13 was discarded.

\section{General Over-All Learning}

A major question asked was, "Do clients learn the jargon during the course of the contract group experience?" Table IV indicates that the thirty-six subjects showed a mean average improvement of 1.5 correct answers from Time 1 to Time 2. 
TABLE IV

MEAN IMPROVEMENT IN LEARNING

\begin{tabular}{|c|c|c|c|}
\hline & $\begin{array}{c}\text { Number of } \\
\text { Time } 1\end{array}$ & $\begin{array}{c}\text { Correct Answers } \\
\text { Time } 2\end{array}$ & Improvement \\
\hline mean & 9.6 & 11.1 & 1.5 \\
\hline$\%$ & $64 \%$ & $74 \%$ & $10 \%$ \\
\hline
\end{tabular}

In spite of mean increase of 1.5 correct answers prom Time 1 to Time 2, Table IV illustrates that inaccurate responses were given to over $25 \%$ of the questions at Time 2. This leaves some doubt as to whether significant learning took place.

Primary and Secondary Words

Table IV revealed that clients do not learn a substantial amount of jargon. However, TA literature claims that there is a relatively small number of words that are important for the client to learn. Berne identifies these words as: "Parent," "Adult," "Child," "script," "game," and "stroke." With the exception of "game," these words were among those receiving unanimous agreement in the word survey conducted with LFS counselors as being very important for the client to know. Table $V$ compares the learning of these five words (labeled "primary words") to the remaining ten words (labeled "secondary words"). 
TABLE $V$

MEAN IMPROVEMENT IN PRIMARY AND SECONDARY WORDS

\section{Number of Correct \\ Answers}

Time 1 Time 2 Improvement

Primary words

\begin{tabular}{cllll} 
& maan & 3.7 & 4.1 & 0.4 \\
$\%$ & $75 \%$ & $82.2 \%$ & $7.2 \%$ \\
\cline { 2 - 4 } Secondary words & & & \\
mean & 5.8 & 7.0 & 1.2 \\
$\%$ & $59 \%$ & $70 \%$ & $11 \%$ \\
\hline
\end{tabular}

While this shows little significant difference in improvement between learning of primary words and secondary words, it does reveal that clients had a greater knowledge of primary words than secondary words before they entered the contract groups.

Retention and Understanding

Because learning consists of understanding as woll as retention, it was decided to ascertain whether both of these factors were present. Questions number $2,3,5,8$, 10, 12 and 15 were constructed to test retention, and questions number $1,4,6,7,9,11,14$ and 16 were constructed to test understanding. Table VI compares these two aspects of learning. 
TABLE VI

MEAN IMPROVEMENT IN RETENTION AND UNDERSTANDING

\begin{tabular}{|c|c|c|c|}
\hline \multirow[b]{2}{*}{ Retention } & \multicolumn{2}{|c|}{$\begin{array}{c}\text { Number of Correct } \\
\text { Answers }\end{array}$} & Improvement \\
\hline & & & \\
\hline mean & 4.1 & 5.1 & 1.0 \\
\hline$\%$ & $62.7 \%$ & $73.4 \%$ & $10.7 \%$ \\
\hline Understanding & & & \\
\hline mean & 5.0 & 5.9 & 0.9 \\
\hline$\%$ & $62.8 \%$ & $73.9 \%$ & $11.1 \%$ \\
\hline
\end{tabular}

This indicates that the subjects' improvement in understanding is no greater than improvement in rote knowledge. Since the retention questions test for different worde than the understanding questions, it cannot be concluded that subjects understand the same terme that they know.

\section{THE CONTRACT GROUP EXPERIENCE}

Table VII shows the relationship between the client's expected degree of success in fulfilling his contract and his evaluated degres of success in achieving this contract. 
TABLE VII

EXPECTATION AND SUCCESS IN FULFILLING CONTRACT

Expected Success

\begin{tabular}{|c|c|c|c|}
\hline & & No & Yes \\
\hline \multirow{2}{*}{$\begin{array}{l}\text { Achieved } \\
\text { Contract }\end{array}$} & No & 4 & 8 \\
\hline & Yes & 8 & 15 \\
\hline
\end{tabular}

From the table it can be concluded that whether or not clients expected success, $66.7 \%$ achieved it. Conversely, regardless of expectations, $33.3 \%$ did not achieve success. Therefore, there seems to be no relationship between the expectation of mesting a contract and the actual achievement of a contract.

Table VII examines the relationship between the client's satisfaction with the client/counselor relationship and the perceived role of the counselor in aiding personal changes.

TABLE VIII

CLIENT/COUNSELOR RELATIONSHIP AND ROLE OF COUNSELOR Role of Counselor in Aiding Personal Changes Not Helpful Helpful

Client/ Counselor Relationship

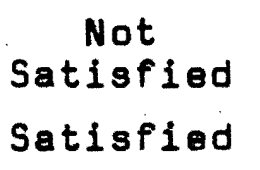

Satisfied

*Tables VII, IX, XI, XV, XVI, XVII, XVIII and XIX have an "n" of 35 because one subject did not make or achieve a contract. 
of thirty-six poople, thirty-three were satisfied with the client/counselor relationship and folt the counselors had helped them in achieving personal chenges. Thus, $92 \%$ of the people were both satisfied with this relationship, and felt they had received help in making personal changes.

TABLE IX

ACHIEVEMENT OF CONTRACT AND PERSONAL CHANGES

Achieved Contract

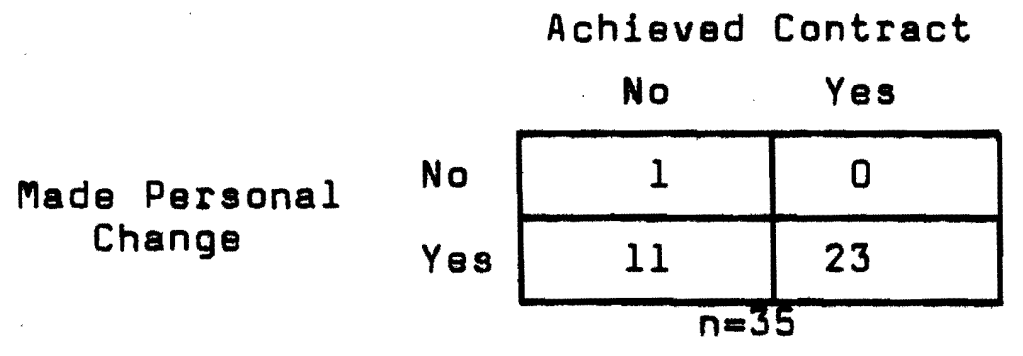

of those who made contracts, $66.7 \%$ felt they had achieved these contracts. On the other hand, $94 \%$ of those who made contracts found the contract group experience helpful in making personal changes. This is a striking difference which indicates that a significant number of clients did not fulfill their contracts. At the same time, they did report personal changes, although the research does not specify the nature or quality of those changes. 
TABLE $X$

ACHIEVEMENT OF CONTRACT AND PERCEIVED

HELP OF COUNSELOR

Role of Counselor in Aiding

Personal Changes

Not Helpful Helpful

Achieved

Contract

\begin{tabular}{|c|c|c|}
\hline & Not Helpful & Helpful \\
\hline No & 2 & 8 \\
\hline Yes & 0 & 23 \\
\hline
\end{tabular}

Whether or not clients achieved their contracts, they credited the counselor with aiding them in making personal changes.

\section{TABLE XI \\ ACHIEVEMENT OF CONTRACT AND CLIENT/ COUNSELOR RELATIONSHIP}

Client/Counselor Relationship Not Satisfied Satisfied

Achieved

Contract

\begin{tabular}{|c|c|c|}
\hline & Not Satisfied & Satisfied \\
\hline No & 1 & 11 \\
\hline es & 0 & 23 \\
\hline
\end{tabular}

Due to the fact that only one client was dissatisfied with the counselor/client relationship, this data reveals no significant relationship.

\section{RELATIONSHIP BETWEEN CONTRACT GROUP \\ EXPERIENCE AND LEARNING OF JARGON}

Most of the general biographic material presented in Chapter $V$ was not compared to learning of jargon. Because * Table X has an " $n$ " of 33 because one subject did not make or achieve a contract and two subjects did not report personal changes. 
this material presented a highly homogeneous group of clients, the question, "Is general learning influenced by the demographic factors of clients in contract groups?" becomes irrelevant.

However, the one issue persued in the demographic data was the relationship between prior knowledge of TA and the learning of TA jargon. The questionnaire contained three items concerning prior.knowledge of TA. One asked if the client had had previous counseling that used TA, another asked if he had taken the Thursday evening TA class, and the last explored whether he had had previous acquaintance with TA through books, public lectures, television programs, etc. Each positive answer was given a value of "l", so that a total "Exposure to TA" scale was devised.

TABLE XII

$$
\text { EXPOSURE TO TA }
$$

\begin{tabular}{ll} 
No exposure & 0 \\
\hline Minimal exposure & 1 \\
\hline Some exposure & 2 \\
\hline Most exposure & 3 \\
\hline
\end{tabular}

Table XIII presents the comparison of this scale to knowledge of TA at Time 1. "Low" and "High" knowledge of TA was determined by dividing the sample in half, based on the extended median of 9.5 correct answers at Time 1 . 
TABLE XIII

EXPOSURE TO TA AND TIME 1

KNOWLEDGE OF TA

Jargon scores at Time 1

Previous Exposure with TA

\begin{tabular}{|c|c|c|c|c|}
\hline & 0 & 1 & 2 & 3 \\
\hline Low & 4 & 9 & 1 & 3 \\
\hline High & 1 & 5 & 10 & 3 \\
\hline
\end{tabular}

As the number of exposures to TA increased, the relative number of high scores also increased. However, when a level of three exposures was reached, the relative number of high scores decreased significantly. Table XIII indicates, therefore, that previous knowledge of TA is not consistently related to test performance.

\section{TABLE XIV}

TA CLASS AND TIME 1 KNOWLEDGE

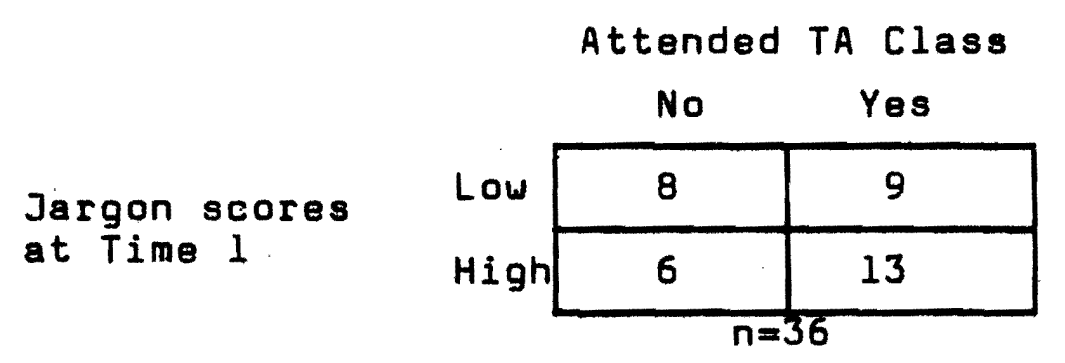

This appears to indicate no relationship between attending the TA Class and knowledge of TA at Time 1. It would appear that the TA Class did not make a significant difference in knowledge of TA jargon at Time 1. 
TABLE XV

\section{PREVIOUS EXPOSURE TO TA AND}

FULFILLMENT OF CONTRACT

\begin{tabular}{|c|c|c|c|c|c|}
\hline & & Prev & $B$ & sur & to $T A$ \\
\hline & & 0 & 1 & 2 & 3 \\
\hline & No & 4 & 5 & 2 & 1 \\
\hline & Yes & 1 & 8 & 9 & 5 \\
\hline
\end{tabular}

TABLE XVI

PREVIOUS EXPOSURE TO TA AND

ACHIEVEMENT OF CONTRACT

Achieved

Contract

Previous Knowledge of TA
No \begin{tabular}{|c|c|c|c|}
\hline 2 & 1 & 2 & 3 \\
\hline Yes & 3 & 6 & 1 \\
\hline 5 & 8 & 5 & 5 \\
\hline
\end{tabular}

Tables $X V$ and $X V I$ present an interesting finding: the greater the previous exposure to TA, the more likely the client is to expect success in mesting his contract. But previous exposure to TA does not seem to have a relationship to the client achieving his contract. In other words, the degree of exposure to TA has more to do with expectations of success than actual achievement. 
TABLE XVII

IMPROUEMENT OF JARGON SCORES AND EXPECTED

SUCCESS IN MEETING CONTRACT

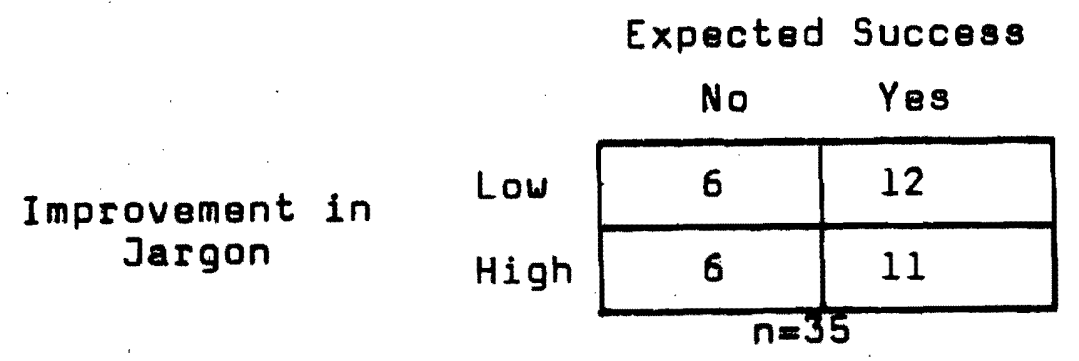

TABLE XVIII

IMPROVEMENT IN JARGON AND

ACHIEVEMENT OF CONTRACT

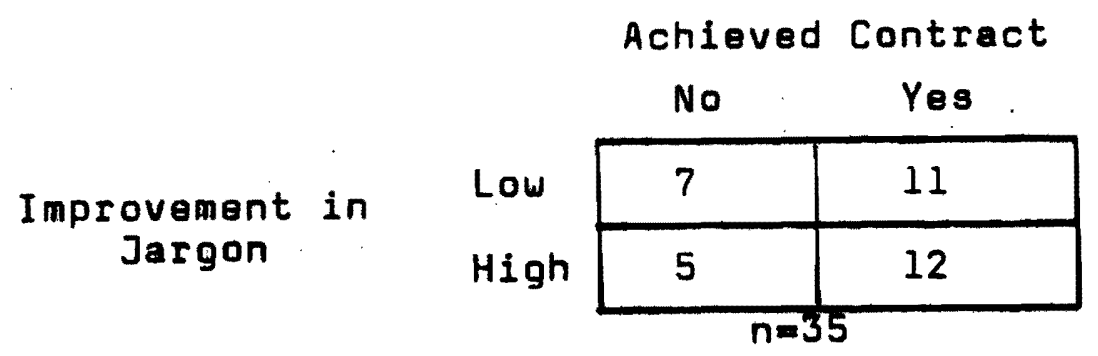

Tables XVII and XVIII neglect to show a significant relationship between the amount of jargon learned during the contract group, client expectations or evaluated degree of success in merting their contracts.

\section{TABLE XIX}

TIME 2 KNOULEDGE AND ACHIEVEMENT

OF CONTRACT

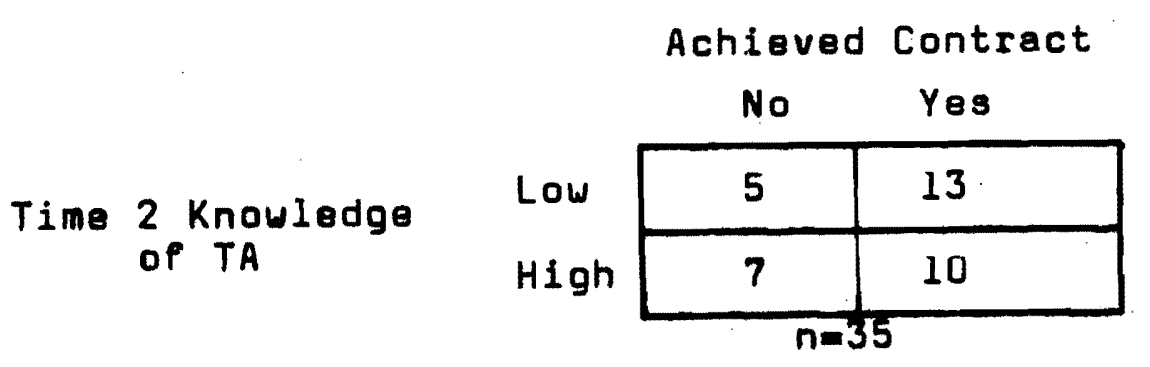

No significant relationship has been shown between 
achievement of contracts, knowledge of TA at Time 1, or amount of increase in knowledge of TA during the contract group. It was speculated that total knowledge of TA jargon, regardless of when or where learned by Time 2, would show a relationship to the achievement of the client's contract. Table XIX indicates that there is no such relationship. 
CHAPTER VIJ

\section{SUMMARY OF FINDINGS}

\section{CONCLUSI ONS}

\section{Boundaries of TA Jargon}

In light of claims that the language of TA is easily understood and identifiable, it was expected that compiling a reliable list of TA terms would be a simple matter. Berne says that TA is a unique language. The findings of the present study indicate that at LFS, at least, an idiasyncratic jargon has been developed.

From tapes of group sessions it was apparent that Gestalt and TA jargons are closely interwoven in practice. Results of the counselor vocabulary survey indicated confusion among counselors as to the actual boundaries of TA jargon. Most confusion was between TA and Gestalt terms, further substantiating the premise that LFS does indeed utilize an idiosyncratic jargon composed of TA and Gestalt elements.

In addition, only twelve of the ninety-three vocabulary survey terms received unanimous ratings as "important" 
by all counselors. This indicates that counselors within the agency vary in their own vocabulary preferences, thus presenting a picture of individual idiosyncratic jargons within the agency.

\section{Population}

Berne expresses strong opinions on the dynamics of group composition. He recommends that groups be composed of as many varying dynamics as possible. This is best achieved by a process of "non-selection", where, through random composition, differences in social class, age, education and degree of poychiatric problems are maximized.

Biographic data shows that the population in the LFS contract groups is largely homogeneous, reflecting group composition very different from the one Berne recommends.

A full $50 \%$ of the members fall within a thirty-one to forty age span; $68 \%$ have had post-high school education; $55 \%$ have been in treatment before coming into the contract group; and $68 \%$ have come with a background in TA theory and/or practice.

These are persons who have committed themselves to a month of intensive counseling, and have agreed to pay a blanket fee covering the entire contract group experience. From this data, it can be concluded that these contract groups were comprised of highly-motivated, well-educated adult individuals, who have an investment in continuing actively 
in therapy, using a treatment modality with which they are already familiar.

\section{Learning of Jargon}

A major focus of this study was the examination of clients' initial knowledge of TA jargon in terms of retention and undergtanding, and the increase in this knowledge during the course of the contract group experience.

Findings based on objective testing revealed that there was a mean increase in total correct responses from Time 1 to Time 2 of only 1.5. Furthermore, there was little difference between improvement in understanding and improvement in retention from Time 1 to Time 2.

Given the wide exposure to TA that members in general had before beginning the group, a higher level of performance was expected at Time 1. Given the twenty-one to twenty-two additional hours of theoretical and experiential contact in the contract group, with a counseling experience which heavily utilizes TA, significant improvement at Time 2 was expected. Neither of the above expectations was met. Whatever the reasons, clients did not come to the contract group with a great degree of TA knowledge, and they did not increase this knowledge significantly while in the group. 
IMPLICATIONS

Jaroon

The improvement of only 1.5 correct responses from Time 1 to Time 2 suggests several possibilities which bear further study: 1) TA jargon may not be as "colloquial" and easily learned as TA proponents claim; 2) perhaps L.FS does not give as much credence as Berne to the notion that it is necessary for therapist and client to learn and understand a mutual TA language; 3) the cognitive learning of TA jargon (although quantitatively prioritized) may not be qualitatively a significant facet of therapy in LFS contract groups.

There is consistent agreement among LFS counselors regarding a small basic TA vocabulary. This is reflected in the fact that clients also learned a limited number of TA words. This may suggest the possibility that consideration be given to paring down TA theory presentations by the agency to a simple skeletal base, utilizing only selected words.

\section{Contract Group Experience}

In the context of the contract group as a "life situation", offering opportunity for behavioral change, a number of implications may be explored. This unique iffe situation is comprised of opportunities to: 1) develop a 
client/counselor rolationship, 2) make a specific contract for change, 3) pulfill that contract, 4) make personal changes, and 5) learn an identifiable jargon. Clients saw this life situation as essentially positive in their subjective evaluation of the contract group experience. One exception is that the learning of TA jargon remained insignificant, both in itself, and in its relationship to the other factors. Virtually all had a good relationship with their counselor, made contracts, and reported achievement of personal changes. Future study regarding the nature of these personal cnanges might yield interesting information.

Socialization

Jerome Frank, in Persuasion and Healing, describes components which work together to "socialize" the client to the psychotherapeutic process. The contract group creates a life situation where these socialization processes occur. Althougn the present study addresses itself primarily to the cognitive aspects of $T A$ in psychotherapy, emotional and behavioral facets cannot be separated from the total picture. According to Frank:

Psychotherapy may be viewed as an influencing process that has emotional, cognitive and bohavioral facets. Emotionally it tries to produce and maintain a degree of arousal optimal for learning, to foster hope, self-confidence, and trust, and to combat despair, insecurity, and suspicion. Cognitively psychotherapy helps the patient to achieve new and more accurate under- 
standing of his problems and ways of dealing with them. From the behavioral standpoint, it requires that the patient participate repetitively in some form of activity that leads to behavioral 4 ghanges outside the therapeutic situation.

Emotions. The emotional facet of psychotherapy, according to Frank, sets the stage for success through establishment of confidence, trust and hope. It provides a favorable milieu, so to speak, where change is likely to occur.

The high degree of confidence expressed by LFS clients in their counselors, and the potency attributed to them in facilitating personal change, indicate that this aspect of the socialization process is currently highly functional.

Future study might make use of a more focused look at what actually goes into the establishment of this relationship. Is it linked to the learning of TA? Frank says, "...the therapist's ability to help his patient depends partly on his self-confidence, and this in turn depends on mastery of a particular conceptual scheme and its accompanying techniques.n 42 Therefore, one might ask, does a therapist's familiarity with TA (or any conceptual framework) result in creating an aura of potency, confidence and authority, whether or not the actual tenets of that framework are transmitted to clients?

This touches on the "true believer" notion, which has been studied extensively, and says, in essence, that 
"at least part of the efficacy of psychotherapeutic methods liss in the shared belief of the participants that these methods will work..." 43 Frank goes on to develop the idea that whether the method be faith-healing, placebo, primitive voodoo, religious revivalism, Communist thought reform, or any of the various methods of psychotherapy, certain common features assure efficacy. These common features make up what essentially is the socialization process described earlier - an atmosphere of trust and hope, learning of tools for change, and opportunities to practice new behavioral skills in everyday life.

Cognition. The present study has failed to show that significant learning of TA jargon occurs in contract groups at LFS. Questions for future exploration might appropriately include: what role, if any, does exposure to TA theory and jargon play in the socialization process at LFS? How do current frameworks for teaching TA at LFS facilitate or inhibit this role? If TA does not "socialize", what does it do for clients?

Behavior. Clients who believe in their counselor and in the efficacy of the conceptual framework he supports, soon seak ways to incorporate these facets into their everyday lives. The present study limits its behavioral aspects to subjective reports from clients regarding behaviors changed or acquired within the contract group situation.

This report involves a select population studied 
over a brief time span. Further information on the behavioral components of TA groups might be acquired by conducting follow-up studies at specified intervals after the group has ended, e.9., 3-month, 6-month and 12-month intervals. Along with exploring the specific nature of personal changes made in the contract group, follow-up studies would measure the permanence of these changes.

Finally, another possibility would be an attempt to study a more stratified, diverse contract group in contrast with the current homogeneous one, to compare both cognitive, emotional, and behavioral aspects of the group experience. To acquire a more global view of TA's overall effectiveness, it may also be productive to extend this study of TA knowledge to the variety of other counseling experiences offered by LFS. 


\section{FOOTNOTES}

1. Berne, Eric. Games People Play. New York: Grove Press, Inc., 1964.

2. Harris, Thomes A. I'm OK-- You're OK. New York: Herper and Row, 1969.

3. James, Muriel and Jongeward, Dorothy. Born to Win:

Transactional Analysis with Gestalt Experiments.

Reading, Massachusetts: Addison-Wesley publishing Company, 1971.

4. Ibid, P. 11,12 .

5. Berne, Eric. Principles of Group Treatment. New York: Oxford University Press, 1964, P. 214.

6. James and Jongeward, Dp cit., $P .1 x$.

7. Berne, Op cit., P. 216.

8. Berne, Eric. Transactional Analysis in Psychotherapy. New York: Grove Press, Inc., 1961, P. I1.

9. Ibid, P. 22 .

10. Webster's Seventh New Colleqiate Dictionary. Springfield, Massachusetts: G. and C. Merriam Company, 1963, P. 454.

11. Steiner, Claude M. MTransactional. Analysis as a Treatment Philosophy," Transactional Analysis Bulletin, I(27)61, July, 1968.

12. English; Fanita. "TA's Disney World," In Psychology Today, 6(11)45, April, 1973.

13. Berne, Op cit., P. 23.

14. Steiner, Op cit., P. 62 . 
15. "Introduction to Transactional Analysis," unpublished material, Lutheran Family Services.

16. Berne, Op cit., P. 169.

17. Steiner, Op cit., P. 63.

18. Ibid., P. 62 .

19. Garry, Ralph and Kinglsey, Howard L. The Nature and Conditions of Learning, 3rd ed., Englewood Cliffs, New Jersey: Prentice Hall, Inc., 1970, P. 404.

20. Meredith, Patrick. Learning, Remembering and Knowing. New York: Association Press, 1961, Pp. 9,10.

21. Ibid, P. 117 .

22. Garry and Kinglsey, Dp cit., P. 415.

23. Underwood, Benton J. and Schulz, Rudolph W. Meaningfulness and Verbal Learning. Chicago: J. B. Lippincott Co., 1960.

24. Merodith, Op cit., P. 10.

25. Ibid, P. 118 .

26. Powell, John W. Research in Adult Group Learning in the Liberal Arts. The fund for Adult Education, 1960.

27. Ripple, Lillian. "Factors Associated with Continuance in Casework Service," Social Work, 2(11)90, January, 1957.

28. Scott, Brian. "Family Services," Five fields of Social Service: Reviows of Research, Henry Mas, ed. New York: National Association of Social Work, 1961, P. 25 .

29. James and Jongeward, Op cit., P. 242.

30. Ferard, Margaret L. and Hunnybun, Nool K. The CaseWorker's Use of Relationships. New York: Charles C. Thomas, 1962, P. 28.

31. Boehm, Bernice. Characteristics of Brief Service and Long Term Cases: A Comparitive Study. Minneapolis, Minnesota: Family and Children's Service, 1961, P.23. 
32. Gandy, John M. and Tapperman, Lorne. nService

Delivery and Client Satisfaction in a Public Neighbourhood Service Centra," The Social Worker, 40(2)82, May, 1972 .

33. James and Jongeward, Op cit., P. 11.

34. Steiner, Op cit., P. 62 .

35. Berne, Op cit., P. 91.

36. Ibid., P. 165.

37. James and Jongeward, Op cit., P. 11.

38. "Counseling Questions," unpublished material, Lutheran Family Services.

39. Berne, Op cit., P. 23.

40. Ibid., P. 23.

41. Frank, Jerome. Persuasion and Healing: A Comparative Study of Psychotherapy. New York: Schoken Books, 1963., P. 167.

42. Ibid., P. 233.

43. Ibid., P. 3 . 
Berne, Eric. Games People Play. New York: Grove Press, Inc., $196 \overline{64}$

Berne, Eric. Principles of Group Treatment. New York: Dxford University press, 1966.

Berne, Eric. The Structure and Dynamics of Drganizations and Groups. Philadephila: Lippincott, 1963.

Berne, Eric. "Transactional Analysis: A New and Effective Method of Group Therapy," American Journal of Psychotherapy, $12(4) 738$, October, 1958.

Berne, Eric. Transactional Analysis in Psychotherapy. New York: Grove Press, Inc., 196I.

Boehm, Bernice. Characteristics of Brief Service and Long Term Cases: A Comparitive Study. Minneapolis, Minnesota: Family and Children's Service, April, 1961.

Brian, Scott. "family Service," In Five fields of Sacial Service: Reviews of Research, Henry S. Maas, ed. New York: National Association of Social Workers, 1966.

Campos, Leonard and McCormick, Paul. Introduce Yourself to Transactional Analysis. Stockton, California: San Joaquin TA Institute, 1969.

"Counseling Questions," unpublished material distributed by Lutheran Family Services, Portland, Oregon.

Crespi, Irving. Attitude Research. New York: American Marketing Association, 1965.

English, Fanita. "TA's Disney World," Psychology Today, 6(11), April, 1973. 
Fagan, Joen and Shepherd, Irma Lee, eds. Gestalt Therapy Now. New York: Harper and Row, 1970.

Ferard, Margaret L. and Hunnybun, Noel K. The Caseworker's Use of Relationships. London: J. B. Lippincott Co., 1962 .

Frank, Jerome D. Persuasion and Healing: A Comparative Study of Psychotherapy. New York: Schoken Books, 1963.

Gandy, John M. and Tepperman, Lorne. "Service Delivery and Client Satisfaction in a Public Neighbourhood Service Centre," The Social Worker, 40(2)76, May, 1972 .

Garry, Ralph and Kinglsey, Howard L. The Nature and Conditions of Learning, 3rd ed. Englowood Cliffs, New Jergey: Prentice-Hall, Inc., 1970.

Haring, Lee. "Berne's Games," ETC: A Review of General Semantics, $27(3) 350$, September, 1970.

Harris, Thomas A. I'm OK - You're OK. New York: Harper and Row, 1969.

"Introduction to Transactional Analysis," unpublished material, Lutheran Family Services, Portland, Oregon.

James, Muriel and Jongeward, Dorothy. Born to Win: Transactional Analysis with Gestalt Experiments. Reading, Massachusetts: Addison-Wesley Publishing Co., 1971.

Levinger, George. "Continuance in Casework and Other Helping Relationships: A Review of Current Research," Social Work, $5(7) 40$, July, 1960.

Meredith, Patrick. Learning, Remembering and Knowing. New York: Association Press, 1961.

Meyers, Michele Tolela. "Transfer Effects of T-Group Training," ETC: A Reviow of General Semantics, 27(4) 465, December, 1970.

Newman, John B. "Sound, Syntax, and Sense--And Meaning," ETC: A Review of General Semantics, 28(2)213, Jung, 1971.

Parad, Lillie and Parad, Howard. "A Study of CrisisOriented Planned Short-Term Treatment," Part I, 
Social Casework, 49 (6) 346, June, 1968; Part II, Social Casework, 49 (7) 418 , July, 1968 .

Paul, Louis. "Freudian Theory, Linguistics, Etc.," ETC: A Review of General Semantics, 27(2)239, June, 1970.

Perls, Frederick S. Gestalt Therapy Verbatim. Lafayette, California: Real People Press, 1969.

Pfouts, Jane H. and Rader, Gordon E. "The Influence on Interviewer Characteristics in the Initial Interview," Social Casework, 43(10)548, December, 1962.

Powell, John W. Research in Adult Group Learning in the Liberal Arts. The Fund for Adult Education, 1960.

Ripple, Lillian. "Factors Associated with Continuance in Casework Service," Social Work, 2(1)87, January, 1957.

Schiff, Jacqui Lee. All My Children. New York: Pyramid Books, 1972.

Steiner, Claude M. "Transactional Analysis as a Treatment Philosophy," Transactional Analysis Bulletin, ?(27), July, 1968 .

Underwood, Benton J. and Schulz, Rudolph W. Meaningfulness and Verbal Learning. Chicago: J. B. Lippincott Co., 1960.

Webster's Seventh New Colleglate Dictionary. Springfield, Massachusetts: G. and C. Merriam Co., 1963.

Werble, Beatrice. "Motivation, Capacity and Opportunity In Services to Adolescent Clients: Major Findings," Social Work, $4(14) 22$, October, 1959.

Wolins, Martin. MMeasuring the Effect of Social Work Intervention," Social Work Research, Norman $A$. Polansky, ed. Chicago: The University of Chicago Press, 1960. Pp. 247-272. 


\section{APPENDIX A}

\section{WORD SURVEY \\ (PRESENTED TO EIGHT COUNSELORS \\ AT LUTHERAN FAMILY SERVICE)}

Your cooperation in filling out this questionnaire will be appreciated. We are interested in the TA terms and phrases which you feel are important for your clients to know in order to effectively engage in treatment at LFS.

Below are 100 words used in psychiatric counseling. please rate each word according to the following scale: $\begin{array}{ccc}\begin{array}{c}\text { Very important } \\ \text { for client }\end{array} & \text { Somewhat impor- } & \text { Not important } \\ \text { to know } & \text { Not for client } & \text { for client } \\ \text { to know } & \text { to know }\end{array}$

This questionnaire will be used in connection with a practicum at PSU School of Social Work. We need the results of this by August 18th. Thank you.

Very Somewhat Not Not TA Impt. Impt. Impt.

top dog

message

archaic elements

child

ego state

transference

dreamuork

duplex transaction

\begin{tabular}{|l|l|l|l|}
\hline & & & \\
\hline & & & \\
\hline & & & \\
\hline & & & \\
\hline & & & \\
\hline & & & \\
\hline & & & \\
\hline & & & \\
\hline
\end{tabular}


Very Somewhat Not Not TA Impt. Impt. Impt.

pay off

decision

homework

"here and now"

potency

contamination

check out

internal primary gain

time structuring

"little professor"

discounting

script

social programing

feedback

awareness

"no win situation"

redecision

secondary gain

adaptive child

pastimes

old tapes

gossip

secondary process

hook

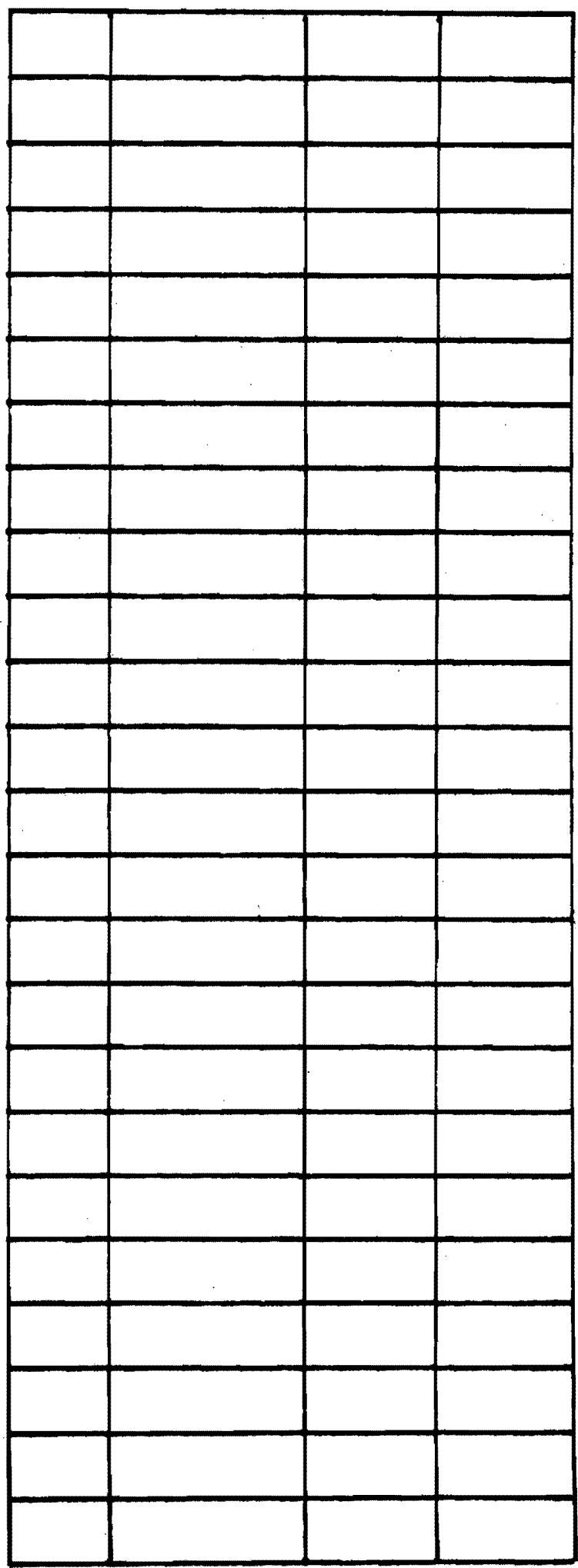


Very Somewhat Not Not TA Impt. Impt. Impt.

decontamination

angular transaction

I'm not OK, You're OK

reward

boundary work

injunction

life script questionnaire

permission

secret message

rackets

counter injunction

I'm not OK, you're not OK

uncrossed transaction

under dog

stroke reserve

actionism

Iituals

conditional stroke

transaction

ego boundary

I'm OK, you're not OK

unconditional stroke

natural child

adult

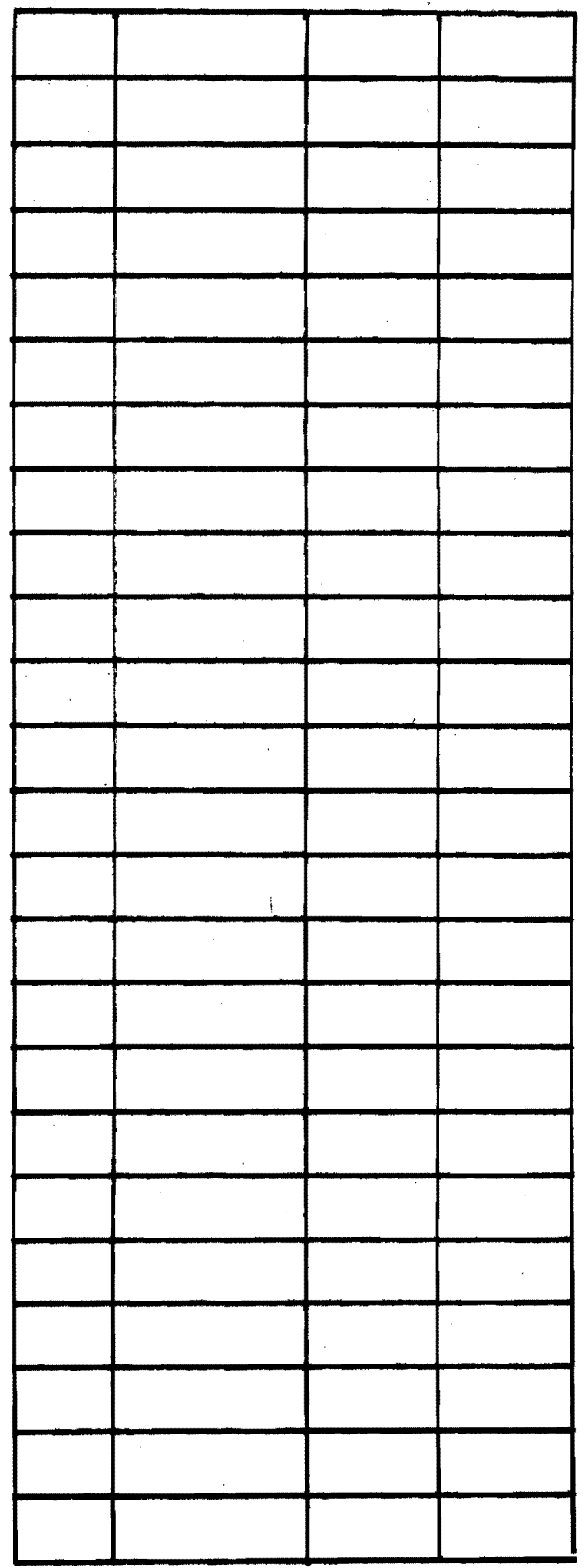


Very Somewhat Not Not TA Impt. Impt. Impt.

cross transactions

gestalt

biological gain

protocol

responsibility

basic position

I'm OK, you're OK

conditioning

exclusion

anxiety

stroke

fantasy

contract

structural action

negative stroke

counter script

off the hook

positive stroke

symbolic stroking

primary gain

games

primary process

structural diagram

trading stamps

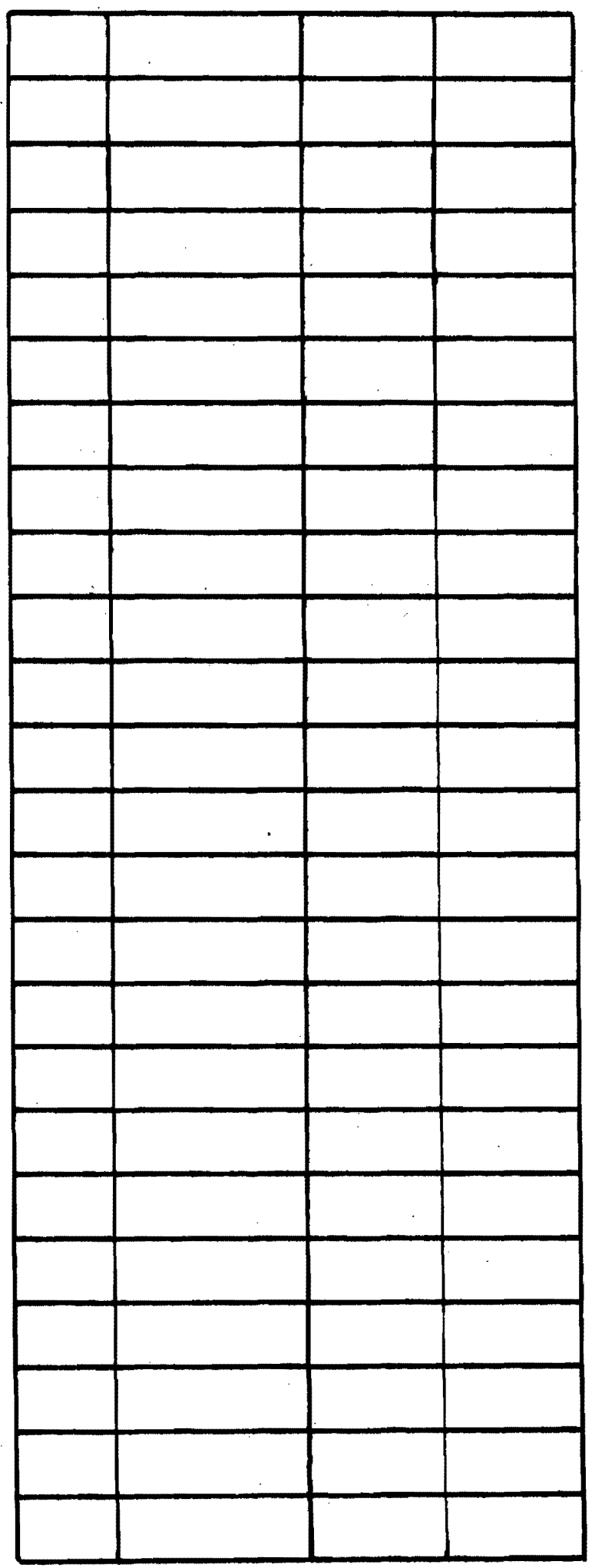


Very Somewhat Not Not TA Impt. Impt. Impt.

educate adult

ulterior transaction

cathexis

con games

"waiting for Santa Claus"

role play

existential message

external primary gain

parent

probability estimation

drama triangle

adaptation

impass8

\begin{tabular}{|l|l|l|l|}
\hline & & & \\
\hline & & & \\
\hline & & & \\
\hline & & & \\
\hline & & & \\
\hline & & & \\
\hline & & & \\
\hline & & & \\
\hline & & & \\
\hline & & & \\
\hline & & & \\
\hline & & & \\
\hline
\end{tabular}




\section{APPENDIX $B$}

\section{RESULTS OF WORD SURVEY \\ (BASED ON RESPONSES OF EIGHT \\ COUNSELORS AT LFS)}

\begin{tabular}{|c|c|c|c|}
\hline core & \% Agreement & Words & \\
\hline 24 & $100 \%$ & $\begin{array}{l}\text { Child } \\
\text { Adult } \\
\text { Parant } \\
\text { decision } \\
\text { stroke } \\
\text { contract }\end{array}$ & $\begin{array}{l}\text { negative stroke } \\
\text { positive stroke } \\
\text { script } \\
\text { redecision } \\
\text { permission } \\
\text { "old tapes" }\end{array}$ \\
\hline 23 & $95.8 \%$ & $\begin{array}{l}\text { message } \\
\text { pay off }\end{array}$ & $\begin{array}{l}\text { racket } \\
\text { time structuring }\end{array}$ \\
\hline 22 & $91.6 \%$ & $\begin{array}{l}\text { basic position } \\
\text { discounting }\end{array}$ & I'm OK, You're OK \\
\hline 21 & $87.6 \%$ & $\begin{array}{l}\text { transaction } \\
\text { educate adult } \\
\text { trading stamps }\end{array}$ & $\begin{array}{l}\text { conditional stroke } \\
\text { I'm not OK, You're OK }\end{array}$ \\
\hline 20 & $83.3 \%$ & $\begin{array}{l}\text { hook } \\
\text { secret message } \\
\text { I'm OK, You're } \\
\text { not OK }\end{array}$ & $\begin{array}{l}\text { counter injunction } \\
\text { I'm not OK, You're } \\
\text { not oK }\end{array}$ \\
\hline 19 & $79.2 \%$ & $\begin{array}{l}\text { ego state } \\
\text { natural child } \\
\text { games } \\
\text { injunction }\end{array}$ & $\begin{array}{l}\text { unconditional stroke } \\
\text { contamination } \\
\text { fantasy }\end{array}$ \\
\hline 18 & $75.0 \%$ & $\begin{array}{l}\text { homework } \\
\text { check out } \\
\text { awareness }\end{array}$ & $\begin{array}{l}\text { counter script } \\
\text { drama triangle }\end{array}$ \\
\hline 17 & - & - & \\
\hline 16 & $66.7 \%$ & $\begin{array}{l}\text { life script } \\
\text { questionnaire } \\
\text { decontamination }\end{array}$ & $\begin{array}{l}\text { cross transactions } \\
\text { adaptive child } \\
\text { pastimes }\end{array}$ \\
\hline
\end{tabular}


Score \% Agreement Words

\begin{tabular}{|c|c|c|c|}
\hline 15 & $62.5 \%$ & $\begin{array}{l}\text { ulterior trans- } \\
\text { action }\end{array}$ & "little professor" \\
\hline 14 & $58.3 \%$ & $\begin{array}{l}\text { "here and now" } \\
\text { rituals } \\
\text { potency }\end{array}$ & $\begin{array}{l}\text { "no win situation" } \\
\text { symbolic stroking }\end{array}$ \\
\hline 13 & $54.2 \%$ & $\begin{array}{l}\text { feedback } \\
\text { uncrossed trans- } \\
\text { actions }\end{array}$ & structural diagram \\
\hline 12 & $50.0 \%$ & anxiety & responsib111ty \\
\hline 11 & $45.8 \%$ & $\begin{array}{l}\text { con games } \\
\text { stroke reserve }\end{array}$ & angular transaction \\
\hline 10 & $41.7 \%$ & $\begin{array}{l}\text { dreamwork } \\
\text { off the hook }\end{array}$ & $\begin{array}{l}\text { duplex transaction } \\
\text { "waiting for Santa } \\
\text { Claus" }\end{array}$ \\
\hline 9 & $36.5 \%$ & cathexis & social programming \\
\hline 8 & $33.4 \%$ & exclusion & \\
\hline 7 & $29.2 \%$ & $\begin{array}{l}\text { gestalt } \\
\text { gossip } \\
\text { role play }\end{array}$ & $\begin{array}{l}\text { archaic elements } \\
\text { ego boundary }\end{array}$ \\
\hline 6 & $25.0 \%$ & $\begin{array}{l}\text { impasse } \\
\text { adaptation } \\
\text { blological gain }\end{array}$ & $\begin{array}{l}\text { structural action } \\
\text { probability estima- } \\
\text { tion }\end{array}$ \\
\hline 5 & $20.8 \%$ & secondary process & \\
\hline 4 & $16.3 \%$ & $\begin{array}{l}\text { conditioning } \\
\text { boundary work } \\
\text { primary process } \\
\text { primary gain } \\
\text { reward }\end{array}$ & $\begin{array}{l}\text { internal primary gain } \\
\text { external primary gain } \\
\text { existential message } \\
\text { secondary gain }\end{array}$ \\
\hline 3 & -- & - & \\
\hline
\end{tabular}




\begin{tabular}{llll} 
Score & P Agreement & Words \\
\hline 2 & $8.3 \%$ & protocol & \\
\hline 1 & $4.2 \%$ & $\begin{array}{l}\text { top dog } \\
\text { actionism }\end{array}$ & transference \\
\hline 0 & $100 \%$ & underdog & \\
\hline
\end{tabular}


APPENDIX C

ESTABLISHED JARGON AT LUTHERAN FAMILY SERUICE*

Adult: The ego state oriented to current reality and the objective gathering of information.

Basic Position: The way one feels about himself and others.

Child: The ego state containing all impulses that come naturally to an infant.

Contract: An Adult commitment to one's self and/or to someone else to make a change.

Decision: A conclusion drawn by the Child ego state early in life about one's self-worth and the worth of others usually based on limited information and experience.

Discounting: The covert or overt lack of response to another's need for strokes.

I'm OK - You're OK: The healthy position towards life which allows one to solve problems constructively and to accept the significance and worth of others and himself.

Message: Verbal or non-verbal communication from external sources about how one is supposed to act or feel.

* These definitions have been adapted from Born to win, I'm OK-You're OK and Introduce. Yourself to Transectional Analysis. 
Negative Stroke: A unit of recognition that helps one feel that he is not-OK (e.g., hating).

0ld Tapes: Complete experiences preserved in serial sequences by the brain.

Parent: The ogo state containing attitudes and behavior incorporated from external sources, primarily parents.

Payoff: The feoling that results from playing a game.

Permission: The act of allowing one's self or another the freedom to change.

Positive Stroke: A unit of recognition that helps one feel that he is OK (e.g., loving).

Racket: Repeated self indulgence in learned feelings such as guilt, inadequacy, hurt, fear or resentment. Redecision: The function of the Adult ego state based on reality testing and probability estimating. Script: A life plan decided upon in childhood. Stroke: Any act implying recognition of another's presence.

Time structuring: A method of describing how people use their time. 
APPENDIX D

THE QUESTIONNAIRE: TIME 1 AND TIME 2

In order to avoid the repetition of sections of the questionnaire which are identical from time 1 to time 2 , the sections will be presented separately.

INSTRUCTIONS: (Used in both Time 1 and Time 2 questionnaires).

last 4 digits of TELEPHONE NUMBER

(or) last 4 digits of SOCIAL SECURITY NUMBER

This questionnaire is the first part of a research project by Lutheran Family Service and Portland State University School of Social Work. You are one of several groups at Lutheran Family Service participating in this project.

You will not be evaluated by your individual performance. Much of the material may be unfamiliar to you. However, IT IS IMPORTANT THAT YOU ANSWER EACH QUESTION, even if yOu are ungure about a question.

There will be a second part to this project, which will be completed at your final Contract Group session. For purposes of this research, we ask that you do not discuss the content of this questionnaire with your group leader or other group members. When the project is completed, information regarding the study will be avallable to you through Lutheran Family Service.

In research projects, it is desirable for participants to remain anonymous. Therefore, do not put your name on the paper. Instead, please write the last 4 digits of your telephone number in the upper right hand corner of the sheet. If you do not have a telephone, put the last 4 digits of your social Security number in the upper right hand corner in the appropriate space. 
Please notice that the questionnaire is made up of two parts:

1. A general information section.

2. A section with a series of questions.

In part I: (General Information)

1. Circle the letter beside the information which applies to you.

2. Be sure to circle ONLY ONE letter for each question.

In part II: (Series of questions)

1. Circle the letter beside the answer which you choose.

2. Please circle ONLY ONE answer to each question.

3. It is important that you ANSWER EACH QUESTION, even if you are unsure about the answer.

Example: Which words are descriptive of apples?
A. Red
B. Fruit
C. Round
(D.) All of the above

There is no time limit. Work at your own speed. Refer back to the instructions if you need to.

REMEMBER: 1. Put the last 4 digits of your PHONE NUMBER or SOCIAL SECURITY NUMBER in the upper right corner of this sheet.

2. ANSWER ALL QUESTIONS.

3. Circle ONLY ONE ANSWER for each question.

Part I (Time 1 only): BACKGROUND INFORMATION

1. My sex is:

A. Male

B. Female 
2. My age is:
A. 19 or 1 ess
B. 20-25
C. 26-30
D. 31-35
E. $36-40$
F. $\quad 41-45$
G. $46-50$
H. 51 \& over

3. The racial group to which I belong is:
A. American Indian
B. Caucasian
C. Negro
D. Oriental
E. Other (specify)

4. Circle the last school grade completed:

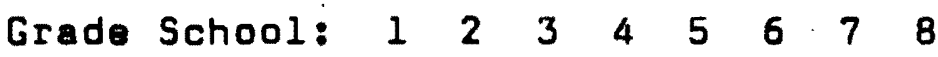

High School: $9 \quad 10 \quad 11 \quad 12$

College: $13 \quad 14 \quad 15 \quad 16$ over 16

5. I have had counseling or therapy before currently applying to Lutheran Family Service:

A. Yes

B. No

If YES, did this therapy or counseling utilize Transactional Analysis ("TA") as a treatment method?
A. Yes
B. No 
6. I have had previous acquaintance with Transactional Analysis ("TA") through such things as books, public lectures, television programs, or pamphlets.

A. Yes

B. No

7. I have attended the evening Introduction to Transactional Analysis ("TA") class offered by Lutheran Family Service:
A. Yes
B. No

8. Some clients have several individual or group interviews at Lutheran Family Service before entering contract groups. I have had the following number of these individual or group sessions:

None, $1,2,3,4,5$ or more

Part I (Time 2 only): GENERAL INFORMATION

1. Since the beginning of the Contract Group, I have increased my familiarity with Transactional Analysis ("TA") through such things as books, public lectures, television programs, or pamphlets:
A. Yes
B. No

2. Since the beginning of the Contract Group, I have attended the evening Introduction to Transactional Analysis ("TA") class offered by Lutheran Family Service:
A. Yes
B. No

3. I made a specific contract (stated goal) at the beginning of the Contract Group:
A. No (If no, skip. to questions 7,8 , \& 9)
B. Yes (If yes, answer questions $4,5, \& 6$ as well as $7,8, \& 9$ )


4. My contract (stated goal) when I entered the Contract Group was to make changes in:

A. The way I felt about myself

B. The way I related to my family (such as parents, brother or sister, spouse)

C. The way I related to others outside of my family

D. The way I related to situations (such as job, school, etc.)

E. Other (specify)

5. When I entered the Contract Group, I expected the following degree of success in fulfilling my contract (stated goal) while a member of the group:

A. Very successful

B. Successful

C. Noutral

D. Unsuccessful

E. Very unsuccessful

6. At the present time, I evaluate the degree of success in achieving my contract (stated goal) as:

A. Very successful

B. Successful

C. Neutral

D. Unsuccessful

E. Very unsuccessful

7. In general, how satisfied were you with the way you and your Lutheran Family Service counselor got along?
A. Very satisfiad
B. Satisfied
C. No particular feelings 
D. Not satisfied

E. Very unsatisfied

8. Did you achieve personal changes in the Contract Group?

A. Yes (If yes, answer question 9 , and then go on to

B. No (If no, go on to Part II.)

9. To what degree did your counselor help you in achieving the personal changes you sought in the Contract Group?

A. Very helpful

B. Helpful

C. No particular feelings

D. Not halpful

E. Very unhelpful

Part II: QUESTIONNAIRE (used in Time 1 and Time 2 questionnaires).

1. Which of the following illustrates the "I'm ok-You're OK" position?

A. I'm always right. I can control others. Nothing you do is ever right. I can't trust anyone but myself.

B. I accept myself. I accept you. I disagree with you, but you are entitled to your beliefs.

C. I'm helpless. I'm defenseless. You're always right. You have all the answers.

D. None of the above.

2. Which phrase best describes a "script"?

A. A series of transactions between two people

B. Fantasies retained in the subconscious 
C. A game used to manipulate others

D. A life plan arrived at in childhood

3. Which ego state contains attitudes and behavior learned from external sources?

A. Little Professor

B. Child

C. Adult

D. Parent

4. During the client's first session in Transactional Analysis ("TA") therapy, he sald, "I want to work out a way to spend more time with my wife, so we can feel closer together." The therapist replied, "I will be happy to work with you on this." This conversation illustrates:

A. Contract

B. Declaration

C. Adult Decision

D. Treatment plan

5. A redecision 18 a function of the:

A. Parent

B. Adult

C. Child

D. All of the above

6. When a couple's new baby wakes up crying, the husband says to his wife, "Just ignore him and maybe he'll shut up." The husband's comment illustrates:
A. Discounting
B. Racket
C. Contamination
D. All of the above 
7. A boy's parents repeatedly tell him to pick up his toys and hang up his clothes. The implied idea,

"Be neat," is best described as:

A. Injunction

B. Message

C. Conditional Stroke

D. All of the above

8. The group of words that best suggests the "Adult" ogo otate is:

A. Gee, wow, won't, can't

B. Correct, reasonable, prectical

C. Beautiful, marvalous, awful

D. None of the above

9. A couple lo holding on to each other for dear life, laughing and ecreaming at the top of their lungs while on roller coaster ride. Which diegram best describes this incident?
A.

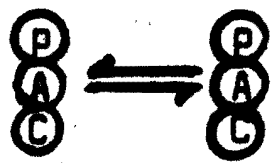
B.

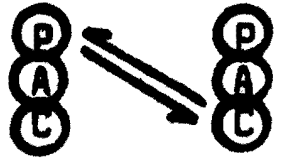
C.

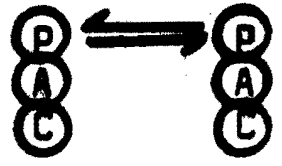
D. $\quad\left(\begin{array}{l}\text { ( }) ~ \\ (\mathrm{C})\end{array}\right.$

10. In Transactional Analysis ("TA"), "permiseion" allows which of the following to happen?

A. Reasurance that one need not change

B. Avolding zesponsibility

C. Allouing one to pay attention to his nold tapes" 
D. None of the above

11. Whenever certain businesamen goes to a party, he spends his time thinking about work he should be doing, rather than enjoying himselp. This is an example of:
A. A game
B. An "old tape"
C. Child feelings
D. A crossed transaction

12. The purpose of a "negative stroken is:

A. To get one's way

B. To offer constructive criticism

C. To send a "not OK" message

D. All of the above

13. A "script" arrived at in childhood depends mainly on:

A. Inherited traits

B. Decisions

C. Conditioning

D. None of the above

14. A mother holds her baby during feeding, and talks to her and siles at her. This is an example of:
A. A stroke
B. A payoff
C. A ritual
D. The "basic position"

15. Withdrawal, intimacy and pastiming are examples op:
A. Rituals
B. Counter injunctions 
C. Games

D. Time structuring

16. Every time Mr. and Mrs. $X$ have an argument, Mrs. $X$ screams and throws things. These outbursts are followed by feelings of guilt and excessive apologies. Mrs. $X$ 's repeated indulgence in guilt feelings is an example of:
A. Contamination
B. Racket
C. Transference
D. Anxiety

17. Make any comments you wish below:

ENDING INSTRUCTIONS (used at the end of both Time 1 and Time 2 questionnalres)

Please double check to see that you have:

1. Answered EVERY question.

2. Circled ONLY ONE ANSWER to each question.

3. Included the last 4 digits of your TELEPHONE NUMBER or SOCIAL SECURITY NUMBER in the space provided. 